\section{Passado, Presente e Futuro}

\section{O que alcançamos, o que aprendemos, onde estamos e onde queremos chegar}

Nascemos de uma iniciativa quase solitária e contávamos com a boa vontade de colegas enviando textos de interesse para os profissionais envolvidos com a Medicina do Esporte. Passamos por uma reestruturação visual gráfica e de conteúdo há pouco mais de sete anos e inauguramos o processo de revisão pelos pares, o qual exige trabalho cotidiano e exaustivo, mas que é indispensável ao periódico que almeja contribuir de fato para o avanço do conhecimento. Adentramos o mundo virtual e passamos a gerenciar todo o processo do periódico pela internet. Ao longo do caminho, conquistamos prestígio junto à comunidade científica, logramos a confiança dos órgãos de fomento e de indexação nacional e internacional, bem como de patrocinadores, mantivemos a regularidade, garantimos a qualidade gráfica e nos tornamos essenciais para aqueles estudantes e profissionais que desejam conhecer a produção científica nacional na área de Medicina do Esporte e ciências do exercício. Hoje somos considerados pelo sistema Qualis da CAPES um periódico de impacto internacional!

Este é um número muito especial para nós, pois entregamos o cargo de Editor-Chefe com a certeza do dever cumprido, após cinco anos. Por esta razão quero agradecer, pois este trabalho não se faz só. Pelo contrário, quanto mais plural e ampliado o grupo de colaboradores, melhor o resultado. Agradeço as diretorias sucessivas da Sociedade Brasileira de Medicina do Esporte, aos editores associados, aos revisores ad-hoc, aos autores e co-autores, à Redprint Editora e à Empresa MZO, responsável pelo sistema na internet. Coordenar os esforços de todos foi um grande privilégio.

Quero aqui também me desculpar, pois reconheço que falhamos em alguns pontos. Apesar das medidas tomadas, o tempo de resposta aos autores ainda é longo, assim como o prazo entre o aceite e a publicação; o sistema na internet precisa ser aperfeiçoado; nosso processo de respostas aos questionamentos deve ser agilizado e o corpo de revisores ad-hoc deve ser ampliado. Entretanto, observem que todos estes pontos que merecem ajustes decorreram tão somente do descompasso entre nossa estrutura e sucesso arrebatador. Falhamos em não termos sido capazes de preparar nosso funcionamento para acomodar a explosão de submissões a partir da entrada no mundo digital e indexação na Scielo (ver gráfico).

Mas como crescer sem financiamento específico? Assim como quase a totalidade dos periódicos no Brasil, dependemos do tra-

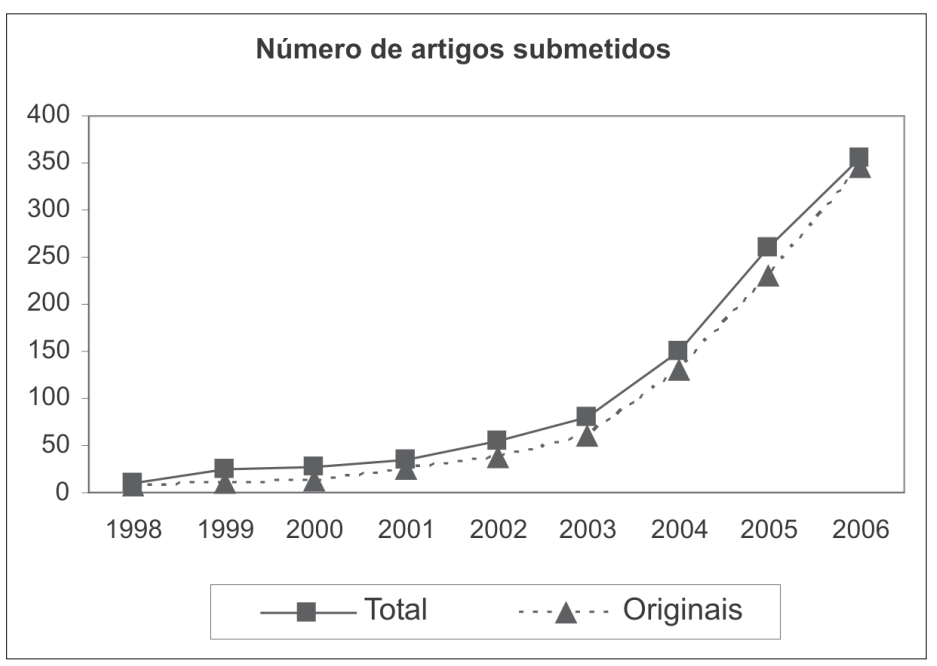

balho voluntário de muitas pessoas. Se, por um lado, é natural que os revisores ad-hoc emitam seus pareceres como parte de suas atividades acadêmicas, como gerenciar centenas de artigos, milhares de revisões e algumas dezenas de milhares de mensagens eletrônicas a cada ano, bem como construir projetos de expansão, emitir relatórios, submeter solicitações de apoio financeiro e de indexação sem contar com profissionais treinados e dedicados a tais funções? Portanto só há dois caminhos: ou encoIhemos ou nos profissionalizamos.

Entregando o cargo de Editor-Chefe à Dra. Renata Castro, profissional jovem mas já com grande experiência com o desporto competitivo de alto nível e como autora de artigos nacionais e internacionais, tenho a plena confiança de que o trabalho será mantido e aperfeiçoado, pois grande parte do sucesso de hoje é resultado do seu trabalho como Editora-Associada. Continuarei colaborando no planejamento estratégico da RBME e na busca de soluções para concretizá-lo agora exercendo a função de EditorSênior e convoco a todos aqueles que viveram nossa transformação nestes últimos anos, assim como nossos novos leitores, autores e colaboradores, a construir um futuro de expansão rumo a novos recordes de quantidade e qualidade. 